Volume 1, Nomor 2, Desember 2020, Hal 87-96

INFOTECH: Jurnal Informatika \& Teknologi

p ISSN 2722-9378 | e ISSN 2722-9386

\title{
PENERAPAN LITURGY BERBASIS ONLINE DI GEREJA KALIMANTAN EVANGELIS JEMAAT YERUSALEM PALANGKARAYA MENGGUNAKAN METODE COBIT
}

\section{ONLINE BASED LITURGY IMPLEMENTATION IN THE KALIMANTAN EVANGELIS CHURCH OF THE JERUSALEM PALANGKARAYA CONGREGATION USING THE COBIT METHOD}

\author{
Frengklin Matatula ${ }^{*}$, Michael Jhonsons ${ }^{2}$ \\ ${ }^{1 *}$ Program Studi Manajemen Informatika, Fakultas Teknik, STMIK Palangkaraya, Kalimantan Tengah, \\ Indonesia 73113. \\ 2 Program Studi Teknik Informatika, Fakultas Ilmu Komputer, Universitas Mercu Buana 11650 Jakarta, \\ Indonesia.
}

\section{Informasi Artikel \\ Article History:}

Submission: 29-11-2020

Revised: $12-12-2020$

Accepted: $21-12-2020$

\section{Kata Kunci:}

Cobit, Liturgi Online, Maturity Model. Teknologi Informasi,

\section{Keywords:}

Cobit, Liturgy Online, Maturity

Model. Information

Technology.

\section{* Korespondensi:}

rfrengklin@gmail.com

\begin{abstract}
Abstrak
Teknologi informasi di era digital sekarang ini merupakan kebutuhan yang penting khususnya pada Gereja Kalimantan Evangelis (GKE) jemaat Yerusalem palangkaraya dimana gereja sendiri harus mengadaptasi perkembangan teknologi untuk peningkatan pelayanan di gereja. Perkembangan teknologi digital membuat gereja mengalami perubahan dari sisi pelayanan salah satunya adalah penerapan multimedia seperti LCD dan slide dalam pelayanan gereja termasuk liturgy atau tata cara ibadah, yang awalnya bersifat cetak, sekarang di sesuaikan dengan proses teknologi digital itu sendiri. Penerapan teknologi liturgy manual terhadap teknologi liturgy berbasis online ini sangatlah penting mengingat perkembangan teknologi digeraja itu sendiri sudah mengalami perubahan oleh karena itu Evaluasi terhadap teknologi informasi di GKE jemaat Yerusalem palangkaraya khususnya liturgy online dengan kerangka kerja cobit dan model maturity model sangat berguna karena dengan adanya evaluasi tersebut gereja dapat mengetahui posisi maturity model dan melakukan perbaikan terhadap teknologi informasi yang sudah dilakukan. Dapat disimpulkan bahwa penerapan liturgi berbasis online hanya menggunakan 4 domain yaitu DS7 (Mendidik Dan Melatih User) DS11 (Mengelola Data), AI7 (Menginstall dan Mengakreditasi Solusi dan Perubahan) AI4 (Menjalankan Operasi dan Menggunkannya), dari 15 responden berdasarkan kuesioner yang dibagikan dan sudah terkontrol dengan baik dan memenuhi standar yang ditetapkan COBIT. Hasil dari analisis Maturity Level pada Gereja Kalimantan Evangelis (GKE) Jemaat Yerusalem belum mecapai yang diharapkan yaitu level 3 untuk tinggat maturity model saat ini dengan total 10,55 dan rata-rata indeks 2,63 masih pada level 2. Hal ini menunjukan bahwa proses penerapan liturgi secara online masih belum optimal dalam meningkatkan kinerja pelayanan khususnya liturgi berbabsis online dikalangan gereja khususnya
\end{abstract}


jemaat.

Abstract
Information technology in today's digital era is an important need,
especially in the Kalimantan Evangelical Church (GKE), the Jerusalem
church in Palangkaraya, where the church itself has to adapt
technological developments to improve services in the church. The
development of digital technology has made the church experience
changes in terms of service, one of which is the application of
multimedia such as LCD and slides in church services including liturgy
or worship procedures, which were originally printed in nature, now
adjusted to the digital technology process itself. The application of
manual liturgy technology to online-based liturgy technology is very
important considering that the development of church technology
itself has changed. Therefore, the evaluation of information technology
at the Jerusalem Palangkaraya Church GKE, especially online liturgy
with the Cobit framework and the maturity model, is very useful
because of the evaluation. The church can find out the position of the
maturity model and make improvements to the information
technology that has been done. It can be concluded that the results of
the application of online-based liturgy only use 4 domains, namely DS7
(Educating and Training Users) DS11 (Managing Data), AI7 ( Installing
and Accrediting Solutions and Changes) AI4 (Running Operations and
Using It), from 15 respondents based on questionnaires that were
distributed and well controlled and met the standards set by CoBIT.
The results of the analysis Maturity Level at the Kalimantan Evangelical
Church (GKE) Jerusalem congregation have not yet reached the
expected level, namely level 3 for the current high maturity model with
a total of 10.55 and an average index of 2.63 which is still at level 2.
This shows that the process of the application of online liturgy is still
not optimal in improving service performance, especially online based
liturgy among churches, especially congregants.

\section{PENDAHULUAN}

Ucapan malah keluhan yang seringkali terdengar mengenai mata pelajaran sejarah gereja berbunyi demikian sejarah gereja hanyalah menghafal saja menghafal tahun-tahun dan namanama yang jumlahnya terlalu banyak memang ada kebenaran dalam ucapan ini sebab tidak mungkin belajar sejarah termasuk sejarah gereja tanpa mempelajari dan menghafal tahun-tahun dan nama-nama tahun-tahun dan nama-nama adalah fakta yang membentuk sejarah dan juga sejarah gereja namun tidak benar kalau dikatakan bahwa sejarah itu terbatas hanya pada awalan saja boleh dikatakan adalah bahan mati tapi bahan mati ini harus dihidupkan[1].

Dalam kamus bahasa Indonesia memberikan selain arti silsilah 2 arti untuk kata sejarah yang perlu diikuti disini pertama-tama Sejarah adalah kejadian dan peristiwa yang benar-benar terjadi pada masa lampau yang kedua pengetahuan atau uraian mengenai peristiwa peristiwa dan kejadian-kejadian yang benar terjadi di masa yang lampau dalam arti kedua ini sejarah sama dengan ilmu sejarah jadi harus dibedakan antara kejadian dan peristiwa. 
Gambaran singkat Sejarah GKE. Hal ini penting mengingat GKE menjadi fokus perhatian dalam studi ini kelak. Bagian ini lebih baik dilihat sebagai membuka tirai cerita menuju cerita yang sesungguhnya. Pertama-tama disadari bahwa krisis sumber bacaan menjadi kendala untuk menjelaskan bagian ini. Tidak banyak sumber sejarah secara tertulis yang dapat dijadikan rujukan. Oleh karena itu, deskripsi ini akan ditampilkan apa adanya. Meskipun demikian, suatu kepastian dapat ditegaskan disini bahwa GKE merupakan produk misi Eropa. Tempatnya produk misi Rheinische Missionsgesellschaft (RMG) dan Basel Mission. Inilah dua lembaga misiyang oleh Fridolin Ukur disebut Zending yang tidak bisa dilupakan ketika berbicara tentang GKE. RMG merupakan lembaga misi asal Jerman. Sedangkan Basel Mission merupakan lembaga misi dari Swiss. Keduanya sama-sama memfokuskan perhatian dan mendedikasikan hidupnya pada upaya pekabaran injil berupa misi luar negeri secara yuridis,

GKE diakui lahir pada tanggal 4 April 1935. Namun, secara sosiologis, gereja lahir pada saat ada orang yang dibaptis. Itu berarti, kelahiran GKE mesti dimulai sejak 10 April 1839. Sebab waktu itulah pertama kali diadakan pembaptisan oleh penginjil Hupperts yang menjadi cikal bakal GKE. Oleh karena itu, sampai tahun 2015, GKE telah mencapai 176 tahun usianya. Johann Heinrich Barnstein merupakan tokoh misionaris yang berhasil mendirikan gereja di Kalimantan bernama Gereja Kalimantan Evangelis yang sebelumnya bernama Geredja Dajak Evangelis. Dengan semangat pelayanan dan penyertaan Tuhan, Johann Heinrich Barnstein dan beberapa penginjil dari Eropa berhasil menanamkan benih Injil di Kalimantan Selatan dan Kalimantan Tengah sampai tahun 1920. Sampai tahun tersebut, mereka berhasil mempersatukan sekitar 5.000 orang ke dalam GKE yang dilayani 14 Pemberita Dayak dan 39 Penatua, 11 Jemaat Induk.

Sesudah kita menguraikan tentang sejarah kita harus mencari definisi kata gereja yakni harus menetapkan apa yang diteliti dan diselidiki oleh ilmu sejarah yang memusatkan perhatiannya kepada gereja apa yang apa yang menjadi objek atau sasaran penelitian sejarah gereja tentang hal ini ada beberapa pendapat yang perlu diperhatikan, pada dasarnya pendapat tentang pokok sejarah gereja dapat dibedakan dua macam ada pendapat-pendapat yang bertolak dari apa yang dapat dilihat dari kenyataan empiris dan ada pendapat-pendapat yang bertolak dari pandangan teologis mengenai gereja yang pertama bertolak dari gereja atau gereja-gereja yang ada secara konkret yang kedua menetapkan suatu ukuran teologis tentang gereja dan kemudian meneliti serta menilai apa dan sampai di mana gereja-gereja yang ada berkesesuaian dengan ukuran-ukuran tersebut sebab kita menetapkan definisi yang kita pilih hendaknya kita uraikan beberapa pendapat yang lazim dari pendapat-pendapat yang menjadi titik tolak dalam kenyataan empiris yang terluas berbunyi demikian sejarah gereja adalah sejarah agama Kristen yang menjadi pokok penelitian menurut definisi ini adalah segala gejala agama Kristen dan segala bentuk yang dipakai manusia untuk mengungkapkan agama kristen ini dengan demikian sejarah gereja menjadi hampir sama dengan ilmu agama hanya diutamakan disini adalah segi Stories dalam agama yakni bagaimana agama-agama diberikan bentuk pada masa lampau dalam definisi-definisi ini gereja hanya hanya salah satu gejala agama Kristen sebagai bentuk yang biasanya dipilih orang Kristen untuk untuk mengorganisasi diri akan tetapi di samping itu masih banyak gejala yang lain walaupun tidak berhubungan dengan gereja[2].

Ketika Injil diberitakan di tengah-tengah Jemaat suku dan bertemu dengan budaya maka adanya pembaharuan nilai-nilai yang dibentuk kepercayaan baru dan mengikat kriswana Si Adi menanggapi pernyataan ini dengan menjelaskan bahwa Injil tidak bisa mengubah budaya lokal dan Jalan satu-satunya melalui asimilasi namun perlu untuk diamati apakah budaya yang dianut adalah budaya yang sesuai dengan Injil atau bertentangan sehingga tidak menjadi problem dalam iman Kristen asimilasi ini terjadi karena budaya yang menjadi kebiasaan manusia tidak 
mudah untuk dipisahkan, hubungan antara budaya dan Injil merupakan masalah yang tidak ada batasnya theodorus kobong menanggapi pernyataan ini dengan berkata perjumpaan Injil dan kebudayaan merupakan sebuah tema klasik dalam pergumulan iman Kristen di tengah dunia ini sejak awal tak bisa melepaskan diri dari kebudayaan, sebab Injil senantiasa hadir dalam totalitas hidup manusia tidak pernah ada Injil yang lepas dari konteks kebudayaan.

Injil tak pernah berada dalam sebuah ruangan yang vacuum secara kultural umat manusia secara universal dan melintasi seluruh kebudayaan dunia namun Injil tidak pernah hadir bagi manusia di luar kebudayaan jika meninjau kembali hubungan antara budaya dan Injil seperti yang diuraikan diatas maka dengan mudah dianalisa bahwa relasi Injil dan budaya akan selalu berada diantara dua kutub yang berlawanan berkaitan dengan hal ini menjelaskan bahwa kutub pertama adalah resistensi atau penolakan kebudayaan ditolak sepenuhnya sebab Injil menegaskan identitas Kristiani yang bisa dengan mudah dicerna dicemari oleh kebudayaan yang terkotori oleh dosa manusia sikap ini bisa muncul dalam dua bagian pertama menolak kebudayaan dengan cara menghindari demi menjaga kemurnian identitas Kristiani kedua menolak kebudayaan namun dengan cara memerangi dan berusaha mentransformasikan menjadi kebudayaan-kebudayaan yang memuliakan Tuhan. Penelitian ini bertujuan untuk mempermudah jemaat dalam mengakses liturgi [3][4][5].

\section{Metode}

Metode yang digunakan dalam penelitian.

a. Studi pustaka

Metode ini dilakukan dengan menggunakan studi literatur dari pustaka-pustaka ilmiah, jurnal, hasil penelitian, e-book, dan literatur penunjang lain yang berkaitan dengan sistem berbasis online [6].

b. Analisis sistem

Analisis data dilakukan dengan pendekatan Cobit dan Maturity Model yang mana dalam penerapan Cobit hanya diambil 4 proses mulai dari pendidikan dan pelatihan, pengumpulan data, solusi dan perubahan serta operasi penggunaan aplikasi sedangkan untuk Maturity Model diterapkan pengukuran sejauh mana aplikasi ini berjalan dan disesuaikan dengan kebutuhan pengguna dan mengambil data-data yang berkaitan dengan liturgy yang ada di Gereja Kalimantan Evangelis. Sementara data-data pendukung lainya diambil dari buku-buku maupun sumber-sumber informasi secara elektronik yang berkaitan dengan permasalahan yang diangkat [7][8][9].

c. Desain sistem

Proses ini digunakan untuk membuat rancangan dasar dari sistem, seperti rancangan konsep rancangan sistem, perancangan antarmuka dan manajemen konten yang disesuaikan dengan hasil evaluasi dari analisis. Rancangan algoritma program dengan menggunakan menggunakan flowchart yang dihasilkan dari aplikasi android studio (ASET), dan desain interface.

d. Implementasi sistem.

Tahap ini merupakan penerapan dari rancangan algoritma, rancangan sistem, dan implementasi yang secara teknis nanti dikerjakan dengan menggunakan program android studio dan untuk database menggunakan ASET dari aplikasi android studio [10].

e. Pengujian Sistem 
Pengujian akan dilakukan terhadap satu kasus atau beberapa kasus penanganan dari suatu fakta di lapangan sampai menghasilkan informasi hasil penelusuran untuk data yang dipakai di dalam aplikasi tersebut [8].

\section{HASIL DAN PEMBAHASAN}

\section{A. Perencanaan menu}

Perencanaan struktur menu merupakan rancangan menu yang digunakan untuk memudahkan pemakaian dalam menjalankan program sehingga pada saat menjalankan program, user tidak mengalami kesulitan dalam memilih menu-menu yang diinginkan. Struktur menu pada sistem ini dapat dilihat pada gambar.

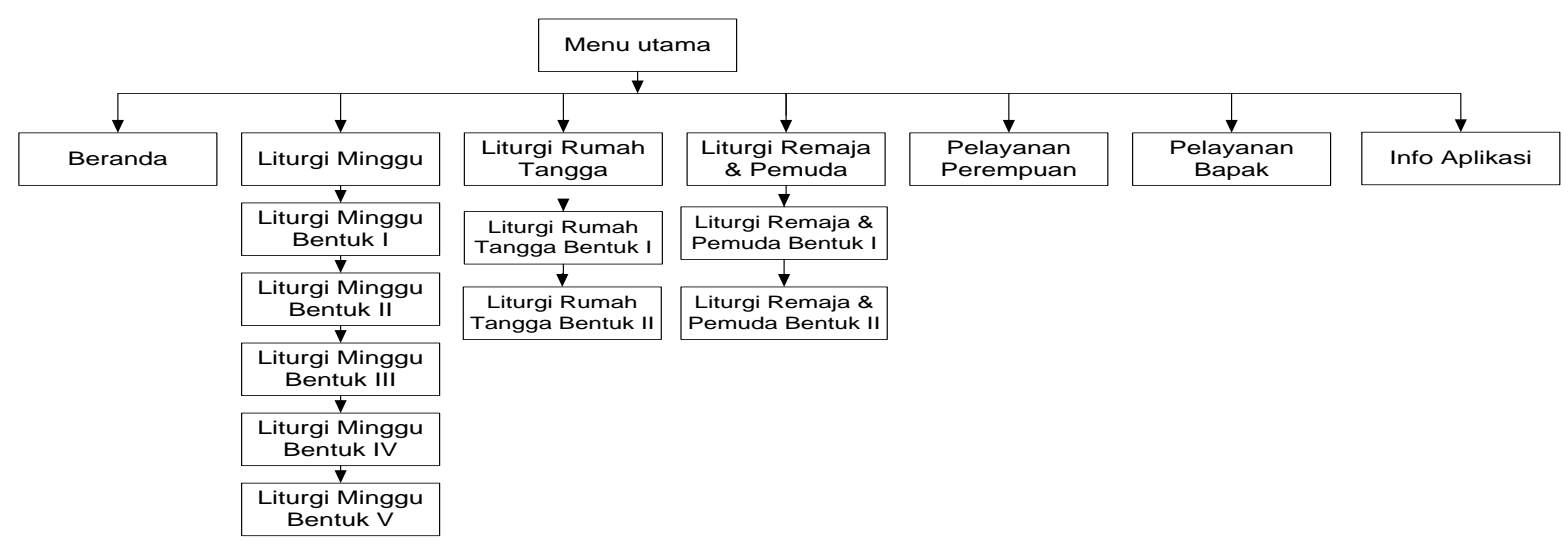

Gambar 2. Perancangan Menu.

Berikut ini adalah hasil aplikasi perancangan.
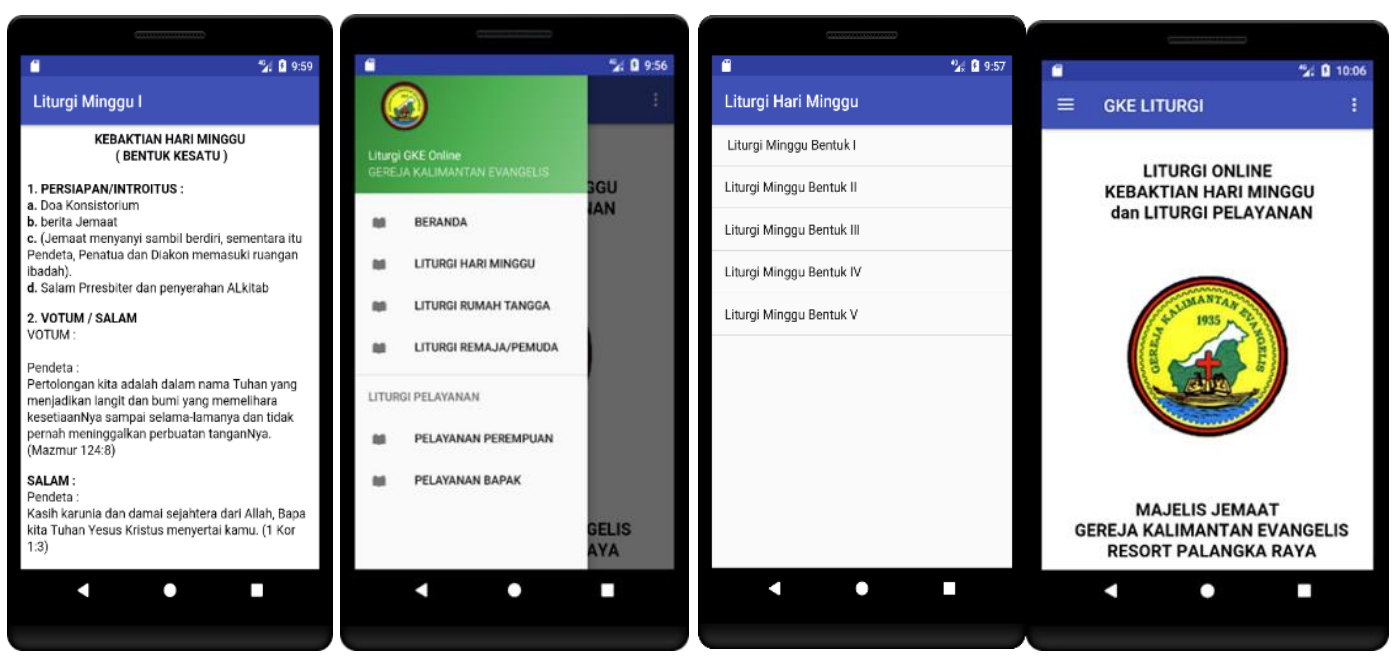

Gambar 3. Aplikasi perancangan.

Hasil penelitian ini diperoleh dari pengumpulan data, populasi, gambaran umum responden, hasil penilaian dan perhitungan kuesioner dari hasil tabulasi data dan untuk mencapai sebuah hasil pemetaan pada tingkat maturity pada sistem aplikasi liturgy berbasis online pada Gereja Kalimantan Evangelis (GKE).

Dari hasil penelitian diketahui bahwa maturity level dari pengaruh teknologi pada liturgy manual terhadap penerapan liturgy berbasis online pada gereja Kalimantan evangelis berada pada level defined, sedangkan target maturity level yang dingin capai gereja Kalimantan evangelis adalah level 3 [11]. 
Hal ini menunjukkan bahwa belum tercapainya target maturity level seperti yang diharapkan oleh gereja Kalimantan evangelis. Untuk meningkatkan pencapaian kinerja sistem penerapan liturgi berbasis online maka peneliti memaparkan beberapa rekomendasi perbaikan sesuai dengan skala prioritas yang telah ditetapkan [12][13].

Tabel 1. Perhitungan kuesioner (lanjutan).

\begin{tabular}{|c|c|c|c|c|c|c|c|c|c|c|c|c|}
\hline \multicolumn{13}{|c|}{ TABULASI DATA } \\
\hline \multicolumn{13}{|c|}{ HIGH LEVEL OBJECTIVES } \\
\hline $\begin{array}{r}\text { Level } \\
\text { Domain }\end{array}$ & $\begin{array}{l}\text { Staf } \\
1\end{array}$ & $\begin{array}{l}\text { Staf } \\
2\end{array}$ & $\begin{array}{l}\text { Staf } \\
3\end{array}$ & $\begin{array}{l}\text { Staf } \\
4\end{array}$ & $\begin{array}{l}\text { Staf } \\
5\end{array}$ & $\begin{array}{l}\text { Staf } \\
6\end{array}$ & $\begin{array}{l}\text { Staf } \\
7\end{array}$ & $\begin{array}{l}\text { Staf } \\
8\end{array}$ & $\begin{array}{l}\text { Staf } \\
9\end{array}$ & $\begin{array}{c}\text { Staf } \\
10\end{array}$ & $\begin{array}{c}\text { Staf } \\
11\end{array}$ & $\begin{array}{c}\text { Staf } \\
12\end{array}$ \\
\hline DS7 & 12 & 13 & 15 & 18 & 15 & 11 & 15 & 11 & 15 & 18 & 12 & 15 \\
\hline DS11 & 11 & 14 & 15 & 13 & 15 & 14 & 11 & 12 & 15 & 12 & 11 & 13 \\
\hline AI7 & 13 & 15 & 14 & 12 & 11 & 21 & 16 & 12 & 16 & 15 & 13 & 12 \\
\hline A14 & 14 & 14 & 15 & 12 & 16 & 11 & 11 & 12 & 15 & 12 & 11 & 15 \\
\hline
\end{tabular}

Tabel 1. Perhitungan kuesioner (lanjutan).

\begin{tabular}{lcccc}
\hline \multicolumn{5}{c}{ TABULASI DATA } \\
\hline \multicolumn{5}{c}{ HIGH LEVEL OBJECTIVES } \\
\hline \multicolumn{1}{c}{ Level } & Staf 13 & Staf 14 & Staf 15 & JML \\
Domain & & & & \\
\hline DS7 & 14 & 11 & 17 & 212 \\
DS11 & 17 & 16 & 15 & 204 \\
AI7 & 15 & 15 & 13 & 213 \\
A14 & 16 & 14 & 15 & 203 \\
\hline
\end{tabular}

Tabel 2. Maturity model.

\begin{tabular}{|c|c|c|c|c|c|c|c|c|c|}
\hline \multirow[t]{2}{*}{ Proses } & \multicolumn{2}{|c|}{ Total Pertanyaan } & \multicolumn{2}{|c|}{$\begin{array}{c}\text { Jumlah Responden } \\
\text { Kuesioner }\end{array}$} & \multicolumn{2}{|c|}{$\begin{array}{l}\text { Total Pertanyaan* } \\
\text { Jumlah Responden } \\
\text { Kuesioner }\end{array}$} & \multirow[t]{2}{*}{$\begin{array}{l}\text { Total nilai } \\
\text { kuesioner }\end{array}$} & \multirow[t]{2}{*}{$\begin{array}{l}\text { Jumlah } \\
\text { Nilai } \\
\text { Jawaban }\end{array}$} & \multirow[t]{2}{*}{ Indek } \\
\hline & $\begin{array}{l}\text { Bagian } \\
\text { IT }\end{array}$ & Pengguna & $\begin{array}{l}\text { Bagian } \\
\text { IT }\end{array}$ & $\begin{array}{c}\text { Penggu } \\
\text { na }\end{array}$ & $\begin{array}{l}\text { Bagian } \\
\text { IT }\end{array}$ & Pengguna & & & \\
\hline DS7 & 6 & 5 & 6 & 81 & 36 & 45 & 81 & 212 & 2,61 \\
\hline DS11 & 5 & 5 & 6 & 75 & 30 & 45 & 75 & 204 & 2,72 \\
\hline AI7 & 6 & 5 & 6 & 81 & 36 & 45 & 81 & 213 & 2,62 \\
\hline A14 & 4 & 6 & 6 & 78 & 24 & 54 & 78 & 203 & 2,60 \\
\hline
\end{tabular}

Berikut pengukuran kuesioner dari hasil kuesioner yang telah diisi oleh responden: Perbandingan maturity level antara responden pengguna dan bagian IT dengan target yang ditetapkan untuk tahun 2017 [14] [15].

Tabel 3. Perbandingan maturity model dengan target.

\begin{tabular}{ccccc}
\hline & Process & \multicolumn{3}{c}{ Maturity Level } \\
\cline { 3 - 5 } & & Sekarang & Skala & Target \\
\hline DS7 & Mendidik Dan Melatih User & 2,61 & 2 & 3 \\
DS11 & Mengelola Data & 2,72 & 2 & 3 \\
AI7 & Menginstall Dan Mengakreditasi Solusi Dan perubahan & 2,62 & 2 & 3 \\
AI4 & Menjalankan Operasi Dan Menggunakannya & 2,60 & 2 & 3 \\
\hline & Total & 10,55 & 2 & 3 \\
\hline & Rata - Rata Indeks & 2.63 & 2 & 3 \\
\hline
\end{tabular}


Berikut adalah hasil evaluasi untuk peningkatan kualitas dari GKE Jemaat Yerusalem terhadap penerapan cobit dalam perkembangan teknologi liturgi secara online.

Tabel 4. Hasil DS7, mendidik dan melatih user.

\begin{tabular}{lll}
\hline Poin & Pembahasan & Rekomendasi \\
\hline DS7 & Gereja mengidentifikasi yang dibutuhkan & Gereja mengadakan pendidikan dan \\
& bagi pengguna dan bagian IT dengan & melatih pengguna maupun bagian IT, \\
& manual book yang dimiliki oleh. Gereja & maka dari itu perlu dipertahankan \\
& Kalimantan Evangelis yang telah & dan ditingkatkan kembali agar kualitas \\
& terdokumentasi, terstandarisasi, dan & pengguna dan bagian IT semakin baik. \\
& dikomunikasikan & \\
\hline
\end{tabular}

Tabel 5. Hasil DS11, mengelola data.

\begin{tabular}{cll}
\hline Poin & Pembahasan & Rekomendasi \\
\hline DS11 & Bagaimana Gereja mengelola data dan & Gereja mengelola data yang \\
& mengupdate data yang dimiliki oleh gereja & dibutuhkan bagi pengguna dan bagian \\
& dan nanti data tersebut akan dikirim ke & IT untuk kedepannya membackup per \\
& kantor Gereja Evangelis Pusat & $\begin{array}{l}\text { hari, minggu, bulan, tahun yang dimiliki } \\
\text { oleh gereja }\end{array}$ \\
\hline
\end{tabular}

Tabel 6. Hasil A17 menginstall dan mengakreditasi solusi dan perubahan.

\begin{tabular}{|c|c|c|}
\hline Poin & Pembahasan & Rekomendasi \\
\hline A17 & $\begin{array}{l}\text { a) Gereja mengajarkan jemaat bagaimana } \\
\text { menginstal dan memakai aplikasi liturgi } \\
\text { berbasis online serta aplikasi ini telah } \\
\text { didokumentasi dengan baik dan } \\
\text { disampaikan kepada pihak terkait. } \\
\text { b) Bagian IT harus selalu mengupdate data } \\
\text { liturgi terbaru yang diberikan dari gereja } \\
\text { Kalimantan evangelis pusat. }\end{array}$ & $\begin{array}{l}\text { a) Gereja melakukan pelatihan } \\
\text { dan penginstalan kepada } \\
\text { jemaat diharapkan kepada } \\
\text { bagian IT membuat handbook } \\
\text { atau tutorial yang bisa diakses } \\
\text { oleh jemaat supaya } \\
\text { mempermudah jemaat dalam } \\
\text { menggunakan aplikasi tersebut. } \\
\text { b) Gereja membuat perencanaan } \\
\text { untuk pembiayaan liturgi } \\
\text { berbasis online ini dapat } \\
\text { diakses di playstore maupun } \\
\text { apple store dengan hal ini } \\
\text { bertujuan untuk melihat } \\
\text { apakah aplikasi liturgi dapat } \\
\text { berfungsi dengan baik dan } \\
\text { saling terintegrasi }\end{array}$ \\
\hline
\end{tabular}

Tabel 7. Hasil AI4 menjalankan operasi dan menggunakannya.

\begin{tabular}{lll}
\hline Poin & Pembahasan & Rekomendasi \\
\hline A14 & liturgi berbasis online ini sesuai dengan & Data - data diakses oleh admin dan \\
& fungsinya dan siapa yang berhak & admin yang berwenang melakukan \\
& mengaksesnya dan mengelola semua data & update, selain itu selalu melakukan \\
& yang ada di aplikasi & pemeriksaan terhadap aplikasi liturgi \\
\hline
\end{tabular}


online apakah sudah sesuai dengan prosedur operasional atau tidak dan jika ada perubahan maka admin akan melakukan maintenance aplikasi tersebut.

Tabel 8. Hasil perhitungan domain delivery and support (DS).

\begin{tabular}{lcccc}
\hline & Process & \multicolumn{3}{c}{ Maturity Level } \\
\cline { 3 - 5 } & & Sekarang & Skala & Target \\
\hline DS7 & Mendidik Dan Melatih User & 2,61 & 2 & 3 \\
DS11 & Mengelola Data & 2,72 & 2 & 3 \\
\hline \multicolumn{2}{c}{ Total } & 5,33 & 2 & 3 \\
\hline & Rata - Rata Indeks & 2.66 & 2 & 3 \\
\hline
\end{tabular}

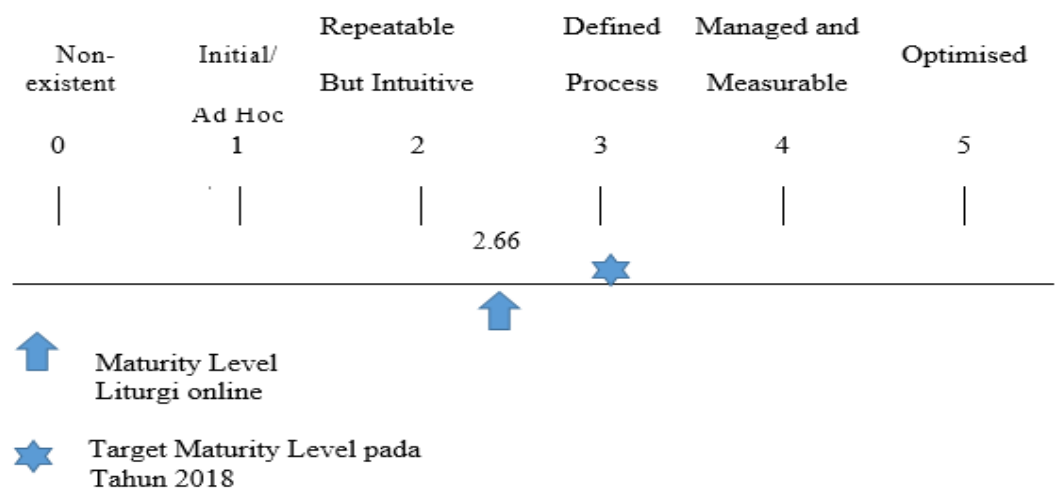

Gambar 3. Maturity model pada delivery and support di GKE jemaat yerusalem.

Pada table 8 dan gambar 3 maturity model tersebut pada delivery and support di GKE Jemaat Yerusalem ini berada pada skala 2.66, sehingga hal-hal yang perlu diperbaiki meliputi DS7 (mendidik dan melatih user) dan DS11 (mengelola data).

Tabel 9. Hasil perhitungan domain acquire and implement (AI).

\begin{tabular}{clccc}
\hline & \multicolumn{1}{c}{ Process } & \multicolumn{3}{c}{ Maturity Level } \\
\cline { 3 - 5 } & & Sekarang & Skala & Target \\
\hline AI7 & $\begin{array}{l}\text { Menginstall dan } \\
\text { mengakreditasi solusi } \\
\text { dan perubahan }\end{array}$ & 2,62 & 2 & 3 \\
AI4 & $\begin{array}{l}\text { Menjalankan operasi } \\
\text { dan menggunakannya }\end{array}$ & 2,60 & 2 & 3 \\
\hline Total & 5,22 & 2 & 3 \\
\hline & Rata - Rata Indeks & 2,61 & 2 & 3 \\
\hline
\end{tabular}




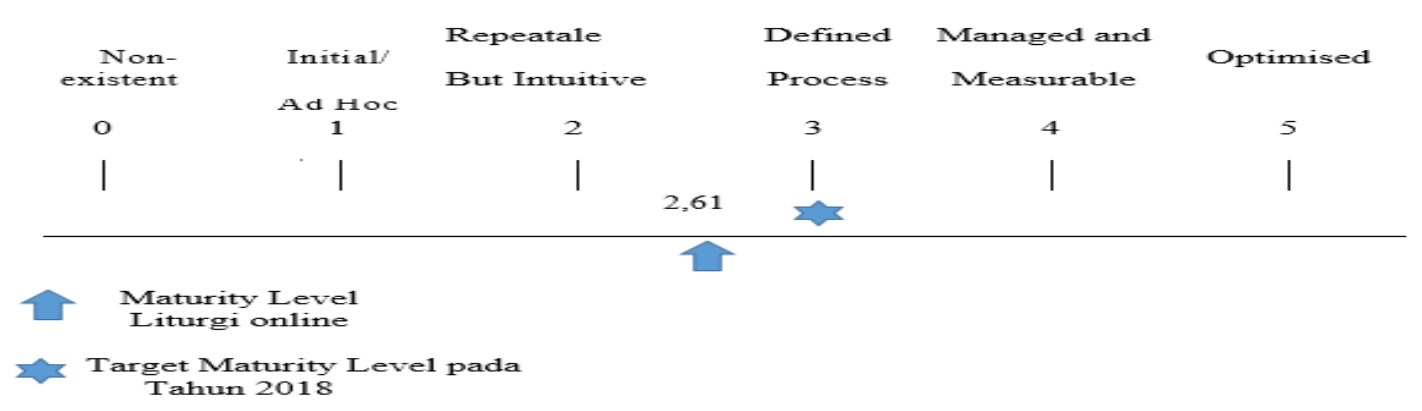

Gambar 4. Maturity model pada domain acquire and implement di GKE Jemaat Yerusalem

\section{SIMPULAN.}

Dari penelitian yang telah dilakukan terhadap gereja kalimantan evangelis (GKE) Jemaat Yerusalem mengenai pengaruh teknologi pada liturgy manual terhadap penerapan liturgy berbasis online di Gereja Kalimantan Evangelis (GKE) Jemaat Yerusalem palangkaraya menggunakan metode cobit adalah sebagai berikut. Hasil dari analisis control objectives ditinjau dari penerapan liturgi berbasis online hanya menggunakan 4 domain yaitu DS7 (Mendidik dan Melatih User) DS11 (Mengelola Data), AI7 (Meng-install dan Mengakreditasi Solusi dan Perubahan) AI4 (Menjalankan Operasi dan Menggunakannya), dari 15 responden berdasarkan kuesioner yang dibagikan dan sudah terkontrol dengan baik dan memenuhi standar yang ditetapkan COBIT, Hasil dari analisis Maturity Level pada Gereja Kalimantan Evangelis (GKE) Jemaat Yerusalem belum mencapai yang diharapkan yaitu level 3 untuk tingkat maturity model saat ini dengan total 10,55 dan rata-rata indeks 2,63 masih pada level 2. Untuk mencapai tingkat kematangan yang diinginkan (expected maturity level) di level 3 (define process) maka semua prosedur yang disyaratkan di setiap proses harus terpenuhi dengan mengacu pada standarisasi cobit untuk setiap bagian dalam gereja harus terlibat langsung baik bidang IT maupun pengguna Hasil goals and metrics untuk 4 domain yang diterapkan adalah: DS7 $=2,61$, DS11 $=2,72$, $\mathrm{AI} 7=2,62, \mathrm{AI} 4=2,60$

\section{REFERENSI}

[1] D. Vol, “Diligentia Vol. 1, No.1 September 2019 Page 101,” vol. 1, no. 1, pp. 101-103, 2019.

[2] K. de Jong, "Misiologi dari Perspektif Teologi Kontekstual," Gema Teol., vol. 31, no. 2, pp. 43-51, 2007.

[3] E. Purwanto, "Dialektika Iman Kristen Dan Kebudayaan Indonesia Berdasarkan Kajian Geert Hofstede the Dialectic of Christian Faith and Indonesian Culture Based on the Study of Geert Hofstede," vol. 1, no. 5, 2019.

[4] D. Triastanti, F. P. Ndiy, and H. Harming, "Strategi Misi Lintas Budaya Berdasarkan Kisah Para Rasul 1: 8," J. Teol. Kontekst. Indones., vol. 1, no. 1, pp. 15-25, 2020.

[5] D. H. R. Pinontoan, "MENUJU TEOLOGI IDENTITAS: Kajian atas Rekonstruksi dan Representasi Moral Kristen Barat terhadap Makna Mu'kur di Minahasa," Indones. J. Theol., vol. 3, no. 1, pp. 1-34, 2015.

[6] Haviluddin, H. J. S. Setyadi, P. P. W. Widagdo, and M. T. Taruk, "Perbandingan Fasilitas Cobit 4.0/4.1 Dan Cobit 5 Frameworks : Studi Pengguna Berdasarkan Literatur," Pros. Semin. Ilmu Komput. dan Teknol. Inf., vol. 1, no. 1, pp. 30-37, 2016.

[7] P. S. Perizinan and P. Survei, "It Governance Dengan Framwork Cobit Di Biro Kuantitatif Deskriptif," vol. 2, no. 2, pp. 29-33, 2013.

[8] A. Suradi and S. Wiyanta, "Penerapan Framework COBIT untuk Identifikasi Tingkat 
Kematangan Tata Kelola Teknologi Informasi: Studi Kasus di Fasilkom Unwidha," Khazanah Inform. J. Ilmu Komput. dan Inform., vol. 3, no. 1, p. 38, 2017.

[9] R. Hastuti, "Pendidikan Agama Kristen Dalam Keluarga Sebagai Pusat Bermisi," J. Antusias, vol. 2, no. 4, pp. 23-68, 2013.

[10] D. Perdana, "Implementasi COBIT Framework Pada Pengauditan Proses Pengembangan Sistem Informasi Akuntansi," vol. 12, no. 1, pp. 1-15, 2009.

[11] K. Perguruan, T. Swasta, D. I. Kota, and B. Supradono, "Tingkat Kematangan Tata Kelola Teknologi Informasi ( It Governance ) Pada Layanan Dan Dukungan Teknologi Informasi," vol. 2011, no. April, 2011.

[12] RDA FAIR Data Maturity Model Working Group, "FAIR Data Maturity Model: specification and guidelines," Res. Data Alliance, pp. 2019-2020, 2020.

[13] L. M. Glavan, "An Investigation of Business Process Maturity: Report on Croatian Companies," Bus. Syst. Res. J., vol. 11, no. 2, pp. 159-165, 2020.

[14] A. Prasetyo and N. Mariana, "Analisis Tata Kelola Teknologi Informasi ( It Governance ) pada Bidang Akademik dengan Cobit Frame Work Studi Kasus pada Universitas Stikubank Semarang," J. Teknol. Inf. Din., vol. 16, no. 2, pp. 139-149, 2011.

[15] R. C. S. Haryono, "Analisis Dan Penilaian Teknologi Informasi Pada Proses Tata Kelola Dengan Cobit 5 Pada Domain Edm Studi Kasus Universitas Peradaban," Indones. J. Bus. Intell., vol. 1, no. 1, p. 25, 2019. 